Article

\title{
Land subsidence, Ground Fissures and Buried Faults: InSAR Monitoring of Ciudad Guzmán (Jalisco, Mexico)
}

\author{
Carlo Alberto Brunori ${ }^{1, *}$, Christian Bignami ${ }^{1}$, Matteo Albano ${ }^{1}$, Francesco Zucca ${ }^{2}$, \\ Sergey Samsonov ${ }^{3}$, Gianluca Groppelli ${ }^{4}$, Gianluca Norini ${ }^{4}$, Michele Saroli ${ }^{5}$ \\ and Salvatore Stramondo 1
}

1 Istituto Nazionale di Geofisica e Vulcanologia, Rome 00143, Italy;

E-Mails: christian.bignami@ingv.it (C.B.); matteo.albano@ingv.it (M.A.);

salvatore.stramondo@ingv.it (S.S.)

2 Dipartimento di Scienze della Terra e dell'Ambiente, Università di Pavia, Pavia 27100, Italy;

E-Mail: francesco.zucca@unipv.it

3 Canada Centre for Mapping and Earth Observation, Natural Resources Canada, Ottawa, ON K1A 0E4,

Canada; E-Mail: sergey.samsonov@nrcan-rncan.gc.ca

4 Consiglio Nazionale delle Ricerche, Istituto per la Dinamica dei Processi Ambientali, Milan 20133, Italy; E-Mails: gianluca.groppelli@cnr.it (G.G.); gianluca.norini@cnr.it (G.N.)

5 Dipartimento di Ingegneria Civile e Meccanica, Università degli Studi di Cassino e del Lazio Meridionale, Via di Biasio, Cassino 03043, Italy; E-Mail: michele.saroli@unicas.it

* Author to whom correspondence should be addressed; E-Mail: carloalberto.brunori@ingv.it.

Academic Editors: James Jin-King Liu, Yu-Chang Chan, Richard Gloaguen and Prasad S. Thenkabail

Received: 14 April 2015 / Accepted: 18 June 2015 / Published: 7 July 2015

\begin{abstract}
We study land subsidence processes and the associated ground fissuring, affecting an active graben filled by thick unconsolidated deposits by means of InSAR techniques and fieldwork. On 21 September 2012, Ciudad Guzmán (Jalisco, Mexico) was struck by ground fissures of about $1.5 \mathrm{~km}$ of length, causing the deformation of the roads and the propagation of fissures in adjacent buildings. The field survey showed that fissures alignment is coincident with the escarpments produced on 19 September 1985, when a strong earthquake with magnitude 8.1 struck central Mexico. In order to detect and map the spatio-temporal features of the processes that led to the 2012 ground fissures, we applied InSAR multitemporal techniques to process ENVISAT-ASAR and RADARSAT-2 satellite SAR images acquired between 2003 and 2012. We detect up to $20 \mathrm{~mm} /$ year of subsidence of the northwestern part of Ciudad Guzmán. These incremental movements are consistent with the
\end{abstract}


ground fissures observed in 2012. Based on interferometric results, field data and 2D numerical model, we suggest that ground deformations and fissuring are due to the presence of areal subsidence correlated with variable sediment thickness and differential compaction, partly driven by the exploitation of the aquifers and controlled by the distribution and position of buried faults.

Keywords: InSAR; ground subsidence; buried faults; ground fissuring

\section{Introduction}

Ground subsidence can be caused by several geological factors, climatic processes and anthropogenic sources, or by the mixing of the above phenomena. The subsidence is frequently linked to intense faulting and opening of fissures in urban areas, generating a significant geologic hazard that needs to be accurately assessed and monitored [1-3]. Both standard InSAR (Interferometric Synthetic Aperture Radar), based on the analysis of a pair of SAR images, and Advanced InSAR (A-InSAR), based on the analysis of series of SAR images, have been applied to assess natural hazards such as processes of slow and/or fast surface movements [4]. InSAR measurements are particularly capable of mapping ground deformation with a very high spatial resolution over a large area, with high precision and a moderate-to-zero cost [5-8]. Among others, SAR processing techniques have been successfully used to study vertical surface movements caused by anthropogenic ground subsidence, like mining $[9,10]$ and the withdrawal of subsoil fluids in combination with loading [11-16]. Urban areas located within confined basins in active tectonic and volcanic environments are especially subject to the dangerous effects of the ground subsidence, faulting and fissuring, due to the combination of neotectonics, seismicity, thick unconsolidated sedimentary deposits and anthropogenic activities [17-19].

One of the intense surface deformations linked with ground subsidence in urban areas occurred in the Mexican area of Ciudad Guzmán (CG) (Jalisco state) [20]. On 21 September 2012, in the center of CG several fissures opened, causing deformations of roads and serious damages to houses and facilities [20,21]. This event was very fast, with no precursors and not related to significant seismic activity. These characteristics, the coexistence of active faults, thick recent sediments and human activities make the CG 2012 fissuring event an interesting case study for the understanding of the mechanisms and evolution of ground deformation in urban areas.

This work presents the results of a detailed field study and InSAR analysis of the CG surface deformations, focusing on the 2003-2012 period. Through the interferometric processing of SAR images of CG and surrounding area with standard and advanced methods, our study attempts to quantify and characterize the behavior of the subsidence deformation processes. Remote sensing data, accurate field mapping of brittle deformations, and numerical modeling of the subsidence process are used in order to propose a genetic model of the observed deformations. The final aim of our paper is to contribute to a better knowledge of ground subsidence in urban areas located within active tectonic and volcanic environments, showing that the integration of InSAR remote sensing, structural fieldwork and numerical modeling is an effective methodological approach for the study of these hazardous geological processes. 


\section{Geological Setting and Ground Subsidence of Ciudad Guzmán}

The Trans-Mexican volcanic Belt (TMVB) is a 1200-km-long active continental volcanic arc originated by the subduction of the Cocos and Rivera plates along the Middle American Trench [22] (Figure 1). Some of the main Mexican cities in the TMVB, such as Mexico City, Querétaro, Morelia, Toluca, Guadalayara, Puebla and CG experience surface subsidence and ground fissuring [17,18,23]. These cities are located in lacustrine basins bounded by fault scarps and volcanic reliefs. The sedimentary fill of the basins is highly heterogeneous in composition and texture, ranging from fine lacustrine sediments to coarse alluvial, colluvial and volcaniclastic deposits [24]. The neotectonic activity, seismic shacking, compaction of unconsolidated recent sediments and human activities, like water withdrawal and ground loading within these basins, have been considered as the principal causes of the occurrence of ground subsidence and subsequent soil fissuring in the urban areas of the TMVB [17,18,23]. CG, with a population of about 100,000 inhabitants, is located in the Mexican state of Jalisco, at $1500 \mathrm{~m}$ a.s.l., inside the Colima Rift, which is the southern branch of the Colima-Tepic-Chapala triple junction in the western sector of the TMVB [17,25-31] (Figure 1).

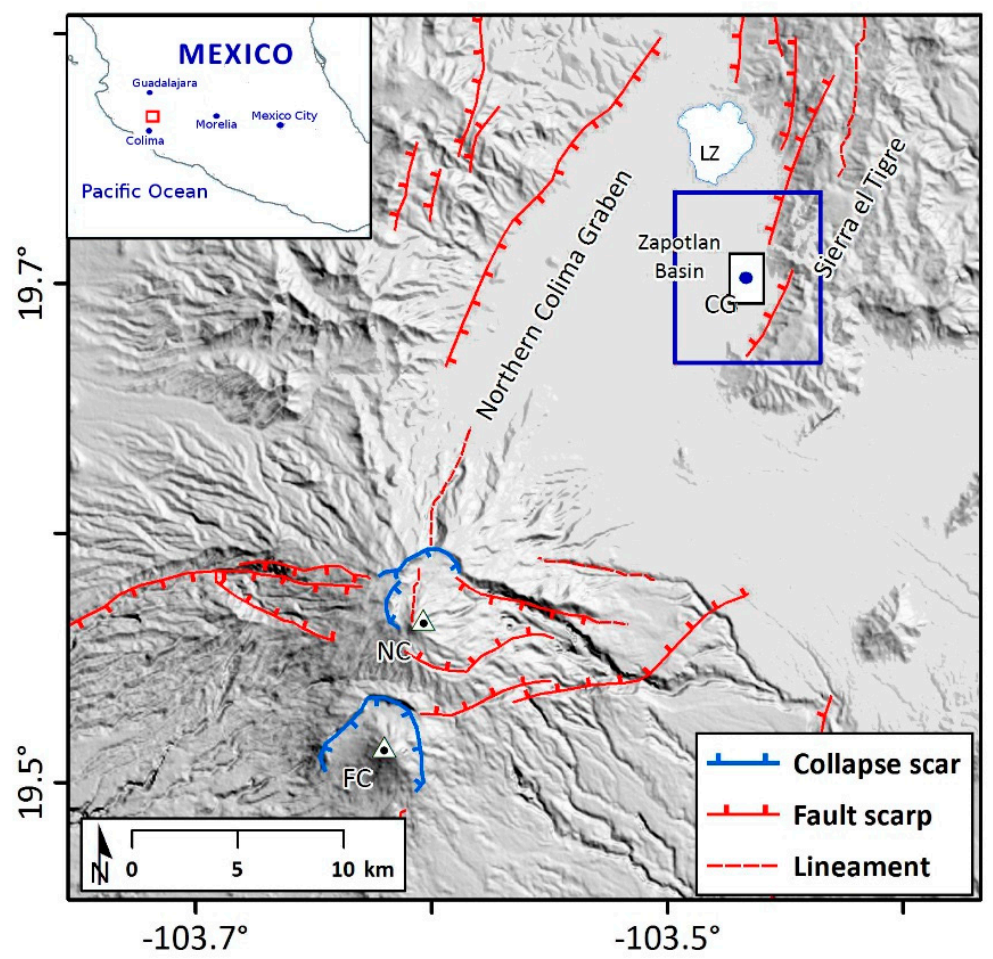

Figure 1. Main tectonic and volcanotectonic structures in the Northern Colima Graben (NCG). The red box in the upper left panel locates the Colima and CG area, the blue box in the main panel locates Figure 2 while the white box locate Figure 3. CG: Ciudad Guzmán, NC: Nevado de Colima volcano, FC: Fuego de Colima volcano, LZ: Laguna Zapoltlan (modified from [32]).

The Colima Rift consists of three structural segments, the Northern Colima Graben (NCG), the Central Colima Graben, and the Southern Colima Graben. The NCG, where CG is located, is flanked by reliefs consisting of Late Miocene-Pleistocene volcanic deposits, Jurassic-Eocene sedimentary and intrusive 
rocks. The depression is floored by Pliocene-Holocene lacustrine sediments, alluvium, colluvium and volcaniclastic deposits of the nearby Colima Volcanic Complex (CVC) [26,27] (Figure 2). The NGC is 20 $\mathrm{km}$ wide and $60 \mathrm{~km}$ long, and flanked by sharp and parallel NNE-SSW-trending active faults. Bounding faults in the NCG dip $70^{\circ}$ toward the graben axis, the relief of their fault scarps is up to $1-2 \mathrm{~km}$, and the mean displacement rate is up to $1-3 \mathrm{~mm} /$ year [26,27,31]. The kinematics of these faults is normal with a minor right-lateral strike-slip component of motion, consistent with a minimum principal stress oriented from E-W to NW-SE [26-28,31].
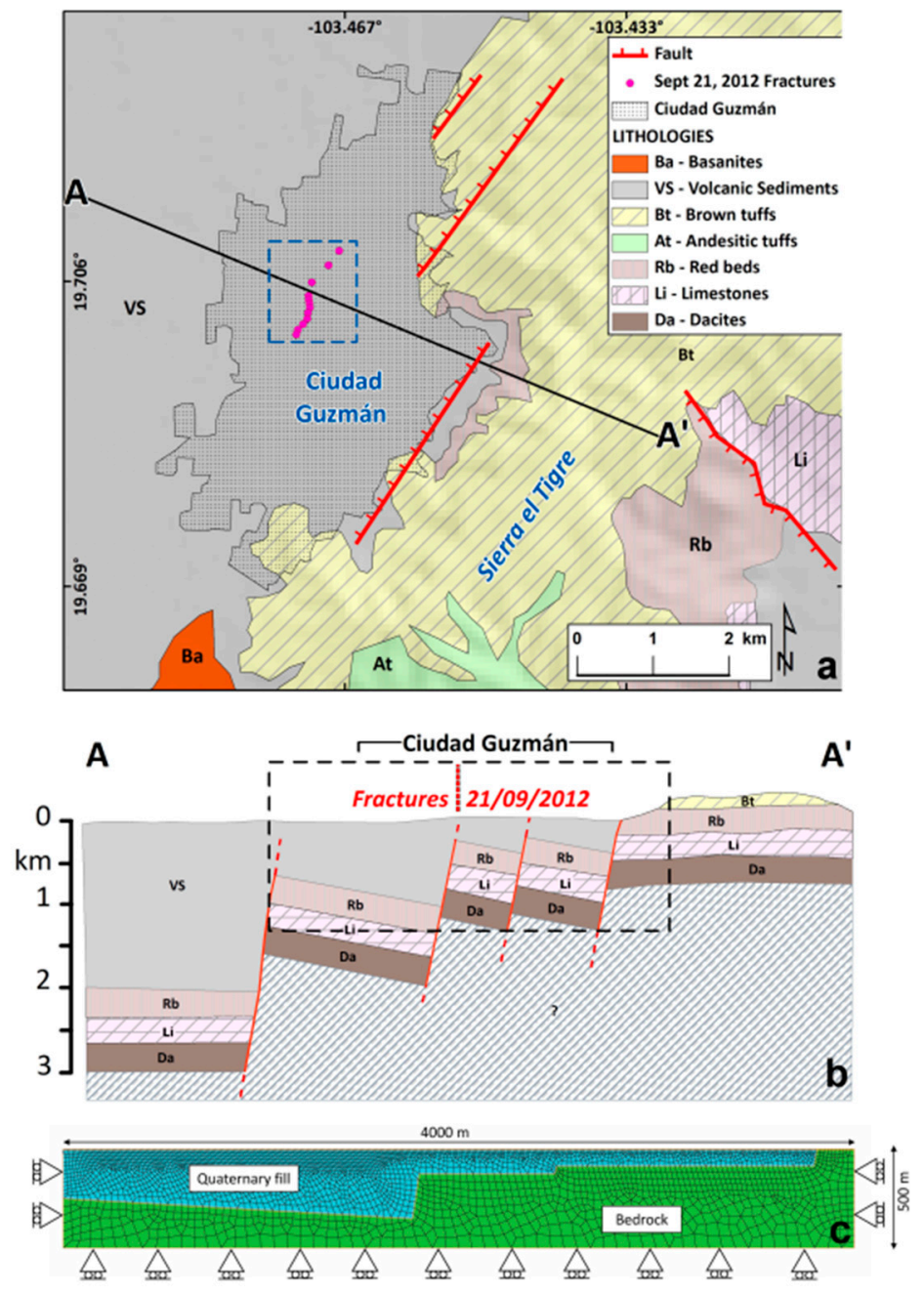

Figure 2. (a) Geological map of Ciudad Guzmán surroundings with the location of the 2012 fissures (purple dots, see Figure 3, here located with light blue dashed box). (Ba) Basanites-Quaternary deposits; (VS) Volcanic Sediments; (BT) Brown Tuffs-Plio-Quaternary deposits; (At) Andesitic Tuffs-Pliocene; (Rb) Red beds-Late Cretaceous; (Li) Limestone; and (Da) Dacites-Early Cretaceous. (b) Geological cross-section of the A-A' trace in Figure 2a, with the location of the 2012 fissures (modified from [32]). (c) Geometry of the finite element model, taken from the black rectangle in Figure 2b. The model has been made with MSC Marc 2013 software [33].

The urban area of CG is bordered to the east by a Cretaceous continental sedimentary sequence exposed along the main fault scarps (red beds), and lies on the graben fill sequence composed of 
volcaniclastic deposits with intercalation of alluvial and lacustrine sediments. The thickness of the mainly unconsolidated graben fill sequence in the CG area ranges from 300 to $1200 \mathrm{~m}$ [32] (Figure 2).

This area is exposed to hazardous natural events such as landslides, volcanic eruptions and earthquakes. The seismic hazard is linked to the main tectonic structures of the volcanic arc and subduction zone, capable of strong earthquakes, and to minor local active faults generating moderate earthquakes $[34,35,36]$. Earthquakes have hit the NCG several times, in 1911, 1931, 1932, 1941 and 1973 [35]. The latest seismic events that affected CG occurred in 1985 (M8.0), 1995 (M7.4) and 2003 (M7.5) [36]. Some of these earthquakes (e.g., 1985) generated ground fissuring in the urban area of the town [37]. In addition, ground fissures opened in CG without any significant seismic shake (e.g. 1993). Indeed, on 21 September 2012, the urban area of CG experienced intense ground fissuring, causing deformations of roads and serious damages to some houses. The 2012 fissures opened in the same location reported for a number of NE-SW striking superficial cracks opened in 1985 and 1993 . These fissures have been associated to the faults cropping out along the border of the graben, which are buried by recent sediments under the urbanized area [21]. The withdrawal of water from the ground has been considered the main driving factor of the surface subsidence and the opening of cracks in the city [20,32,38]. The upper sediment sequence under the urban area consists of heterogeneous sediments with relatively low cohesion, that can be affected by water table dynamics and piping [32].

\section{Urban Survey and Structural Measurements}

A fast urban survey has been performed in CG in November 2012 to describe and measure the deformations (Figure 3) of 21 September 2012. We walked along the CG streets speaking with the residents about the phenomenon of September 2012 and describing faults and fissures, affecting recent anthropic structures, and measuring their strike and displacement with compass and ruler. In Table 1, direct observations of fissures are reported. Locally the deformation pattern is represented by dispersed fissures along the roads, house walls and fences or is not visible because of rapid fixing (mainly for the main streets). The faults and fissures strike $\mathrm{N} 0^{\circ}-20^{\circ} \mathrm{E}$, also showing local variability due to the anisotropic behavior of manmade infrastructure. The entire deformation area is characterized by slight bends, both left and right (Figure 3) and locally the structures show en-echelon arrangement (e.g. Figure $4 \mathrm{~b}, \mathrm{c}$ ). The deformation pattern is almost continuous (more than $1 \mathrm{~km}$ long) and affects a narrow area (few to tens of meters). Only the main evidences are described in Table 1 along with the measured displacements. In general the deformations show vertical displacement $(10$ to $30 \mathrm{~cm})$ with a minor right lateral component of a few millimeters to $2 \mathrm{~cm}$ (Figure 4).

Speaking with the owners of the damaged houses and other eyewitnesses, none describes any earthquake associated to these movements. Some of them said that two to three deformations happened very close together (within about 15 minutes). A house, destroyed by the 1985 earthquake, and now made of wood, has been affected again and partially damaged (point 1, Figures 3 and 4a). 


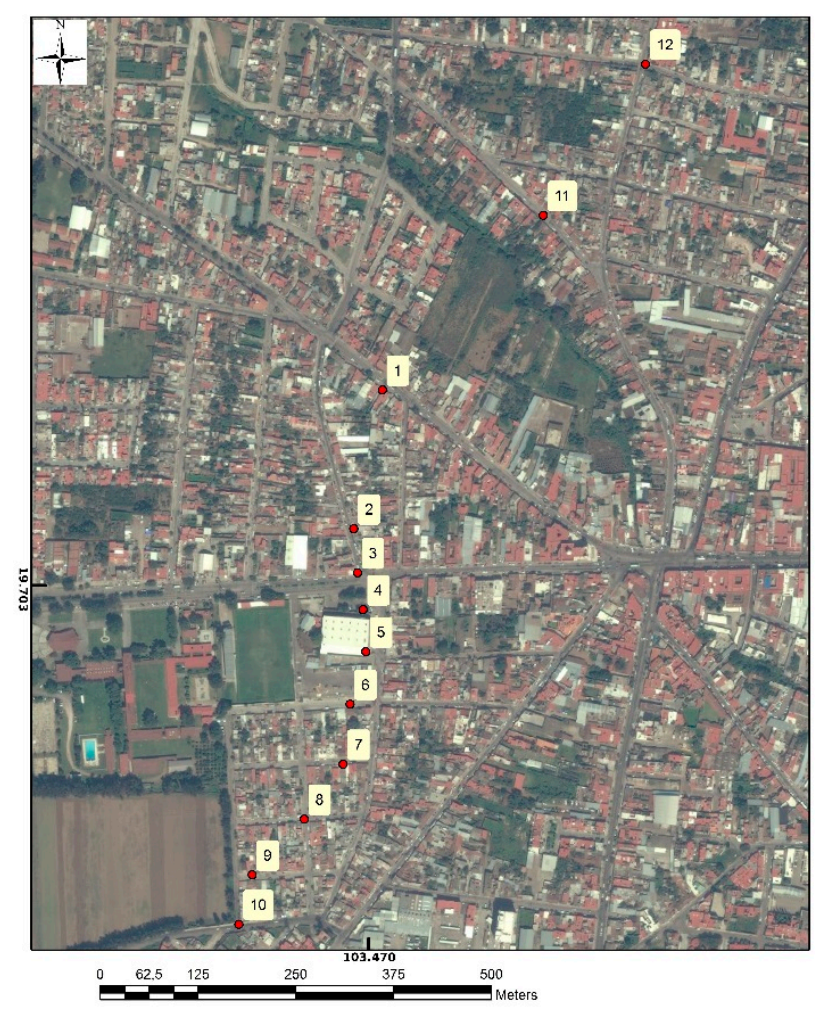

Figure 3. Main sites where faults and fissures affected Ciudad Guzmán on 21 September 2012. Numbers refer to the site described in Table 1. Representation on ESRI basemap imagery service. See Figure 2 to locate the area.

Table 1. Faults and fissures in Ciudad Guzman produced in September 2012. Strike-slip offsets have right-lateral sense of motion.

\begin{tabular}{|c|c|c|c|c|c|c|c|}
\hline $\begin{array}{l}\text { Location } \\
\text { Figure 3) }\end{array}$ & Fissures & Faults & $\begin{array}{c}\text { Vertical } \\
\text { Offset (cm) }\end{array}$ & $\begin{array}{l}\text { Strike-Slip } \\
\text { Offset (cm) }\end{array}$ & $\begin{array}{l}\text { Displaced } \\
\text { Material }\end{array}$ & Note & Pictures \\
\hline 1 & $\mathrm{X}$ & $\mathrm{X}$ & 35 & $1-2$ & $\begin{array}{l}\text { Road and the house } \\
\text { located along } \\
\text { the north side }\end{array}$ & $\begin{array}{c}\text { The house has been destroyed } \\
\text { in } 1985 \text { by the earthquake. } \\
15^{\circ} \mathrm{N} \text { striking }\end{array}$ & $4 \mathrm{~A}$ \\
\hline 2 & $\mathrm{X}$ & $\mathrm{X}$ & & & $\begin{array}{l}\text { Pavement } \\
\text { and fences }\end{array}$ & $\begin{array}{l}\text { Mainly fissures, some of them } \\
\text { showing } 1-2 \mathrm{~cm} \text { offset }\end{array}$ & \\
\hline 3 & & $\mathrm{X}$ & $20-25$ & & Road & $\begin{array}{l}\text { No fissures visible because } \\
\text { the road has been repaired }\end{array}$ & 4B \\
\hline 4 & $\mathrm{X}$ & $\mathrm{X}$ & 12 & 3 & Pavement & $0^{\circ} \mathrm{N}$ striking & $4 B$ \\
\hline 5 & $\mathrm{X}$ & $\mathrm{X}$ & 15 & 2 & Pavement & $5^{\circ} \mathrm{N}$ striking & $4 \mathrm{C}$ \\
\hline 6 & $\mathrm{X}$ & $\mathrm{X}$ & 15 & & $\begin{array}{c}\text { Parking, } \\
\text { Pavement and Road }\end{array}$ & $\begin{array}{l}\text { Partially repaired. } \\
10^{\circ} \mathrm{N} \text { striking }\end{array}$ & 4D \\
\hline 7 & $\mathrm{X}$ & & & & Road and house & $\begin{array}{l}\text { Mainly fissures, some of them } \\
\text { showing mm offset }\end{array}$ & \\
\hline 8 & $\mathrm{X}$ & & & & $\begin{array}{l}\text { Shop and } \\
\text { road at the corner }\end{array}$ & $\begin{array}{l}\text { Mainly fissures, some of them } \\
\text { showing mm offset }\end{array}$ & \\
\hline 9 & $\mathrm{X}$ & $\mathrm{X}$ & 5 & & Road & Mainly fissures in a wide area & \\
\hline 10 & & $\mathrm{X}$ & 8 & 4 & Road and wall & $10^{\circ} \mathrm{N}$ striking & $4 \mathrm{E}$ \\
\hline 11 & & $\mathrm{X}$ & 18 & & Road and wall & $20^{\circ} \mathrm{N}$ striking & $4 \mathrm{~F}$ \\
\hline 12 & $\mathrm{X}$ & $\mathrm{X}$ & 7 & & Road & $15^{\circ} \mathrm{N}$ striking & \\
\hline
\end{tabular}



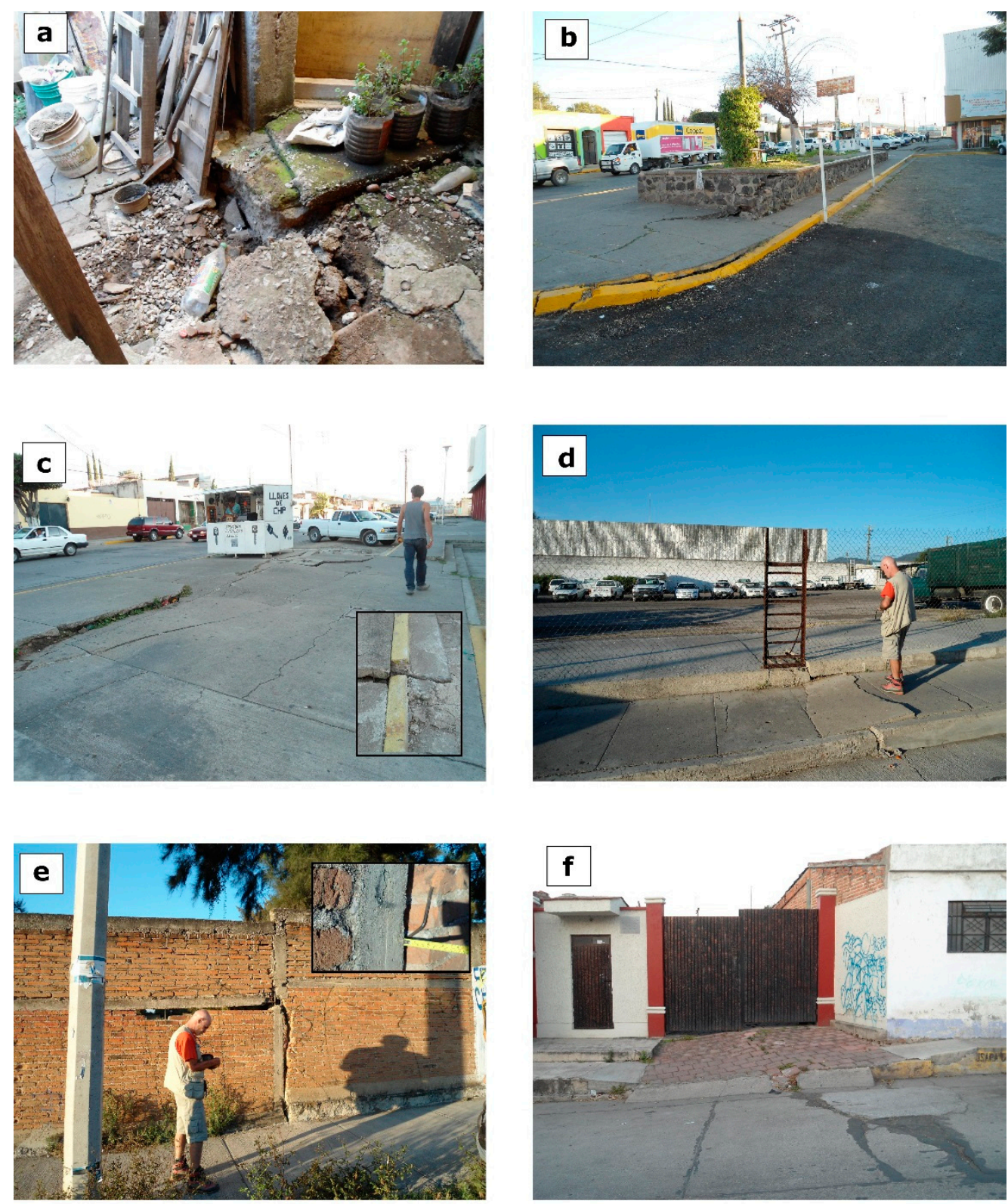

Figure 4. Photos showing evidences of ground fissures and faulting: (a) deformed and fractured pavement (site 1); (b) crossroads and sidewalk showing the pavement displaced and partially repaired (sites 3 and 4); (c) sidewalk affected by normal fault with a minor strike slip offset, as visible in the inset (site 5); (d) parking affected by fissures and normal faults (site 6); (e) sidewalk and wall affected by normal fault associated with a strike slip offset, as visible in the inset (site 10); and (f) street, sidewalk and gate affected by normal displacement (site 11). For the location, see Figure 3.

\section{InSAR Analysis: Methods and Results}

We analyzed ground deformation in the CG area by applying the classical and multi-temporal InSAR techniques to the 2003-2010 ENVISAT and 2012 RADARSAT-2 data (Table 2). In order to investigate the ground deformation during 2003-2010 period (prior to the rupture), we used 40 ascending and 41 descending ENVISAT images acquired by the ASAR (Advanced Synthetic Aperture Radar) sensor during March 2003-October 2009 and December 2003-August 2010 periods, respectively. These two 
sets of images were processed with the Multi-Baseline method implemented in GAMMA software [39]. This method computes deformation time series and residual topographic heights using the Singular Value Decomposition (SVD) Least-Squares inversion technique [40,41]. All interferograms were computed with a multi-look factor of $1 \times 5$ in range and azimuth directions, respectively, leading to a 20 $\times 20 \mathrm{~m}$ pixel on the ground. After the computation of the interferograms, only coherent points, i.e., pixels characterized by signal-to-noise-ratio of the interferometric phase higher than 1.3 were selected. This resulted in a stack of 42 ascending and 58 descending point-wise interferograms used for the SVD inversion. The velocity fields computed from ascending and descending data are shown in Figure 5. Both velocity maps show a Line Of Sight (LOS) distance increase (surface movement away from the satellite, i.e., subsidence) in the area NW of CG. This area is confined by the location of the 2012 surface fissures (Figures 2, 3 and 5). The other side of the ruptures alignment (Eastern side of CG) is stable. It is worth noting that a step gradient in the surface velocity is located exactly where the surface cracks appear. The deformation rates measured by ENVISAT InSAR dataset in the subsiding area reach values of up to $25 \mathrm{~mm} /$ year for ascending data and of about $17 \mathrm{~mm} /$ year for descending data, and both deformation fields show similar spatial pattern.

Table 2. The ENVISAT 2003-2010 dataset (left); and list of interferograms created using four 2012 RADARSAT-2 images (6 March; 26 June; 6 September; 11 December) (right).

\begin{tabular}{|c|c|c|c|c|c|c|c|c|c|}
\hline \multicolumn{8}{|c|}{ ENVISAT } & \multicolumn{2}{|c|}{ RADARSAT-2 } \\
\hline \multicolumn{4}{|c|}{ Ascending Orbit-Figure 5a } & \multicolumn{4}{|c|}{ Descending Orbit-Figure 5b } & \multirow{3}{*}{\begin{tabular}{l}
\multicolumn{1}{c}{ Interferogram } \\
$20120306-$ \\
20120626 \\
$20120626-$ \\
20120906
\end{tabular}} & \multirow{2}{*}{$\begin{array}{l}\text { Figure } \\
8 \mathrm{~A}\end{array}$} \\
\hline 20030117 & 20040416 & 20050506 & 20060804 & 20030124 & 20050826 & 20061020 & 20061020 & & \\
\hline 20030328 & 20040521 & 20050610 & 20061117 & 20031205 & 20050930 & 20061124 & 20061124 & & $8 \mathrm{~B}$ \\
\hline 20030502 & 20040730 & 20050715 & 20061222 & 20040319 & 20051104 & 20061229 & 20061229 & $\begin{array}{l}20120906- \\
20120306\end{array}$ & 9 \\
\hline 20030815 & 20040903 & 20050819 & 20070126 & 20040423 & 20051209 & 20070309 & 20070309 & & \\
\hline 20030919 & 20041008 & 20050923 & 20071207 & 20040528 & 20060113 & 20070413 & 20070413 & & \\
\hline 20031024 & 20041112 & 20051028 & 20080912 & 20040806 & 20060217 & 20070518 & 20070518 & & \\
\hline 20031128 & 20041217 & 20051202 & 20081121 & 20041119 & 20060428 & 20071005 & 20071005 & & \\
\hline 20040102 & 20050121 & 20060106 & 20090306 & 20050513 & 20060602 & 20071109 & 20071109 & & \\
\hline 20040206 & 20050225 & 20060317 & 20091211 & 20050617 & 20060707 & 20071214 & 20071214 & & \\
\hline 20040312 & 20050401 & 20060526 & 20100813 & 20050722 & 20060915 & 20090313 & 20090313 & & \\
\hline & & & & & & & 20100924 & & \\
\hline
\end{tabular}

The applied processing methodology allowed estimation of time deformation histories for each of the coherent points identified in the SAR scene. Figure 6 shows an example of such time series for three points characterized by three different behaviors. Point A in Figure 6 has almost flat horizontal trend, i.e., it is representative of a stable area. Point B experiences a subsidence of about $-15 \mathrm{~mm} / \mathrm{year}$; for this point very small oscillations are visible. Point $\mathrm{C}$ shows a higher rate of subsidence, of about $-22 \mathrm{~mm} /$ year, with similar oscillations as point $\mathrm{B}$, but more pronounced. The observed oscillations seem to be regularly distributed in time and are likely due to seasonal recharge and discharge of the aquifers. 


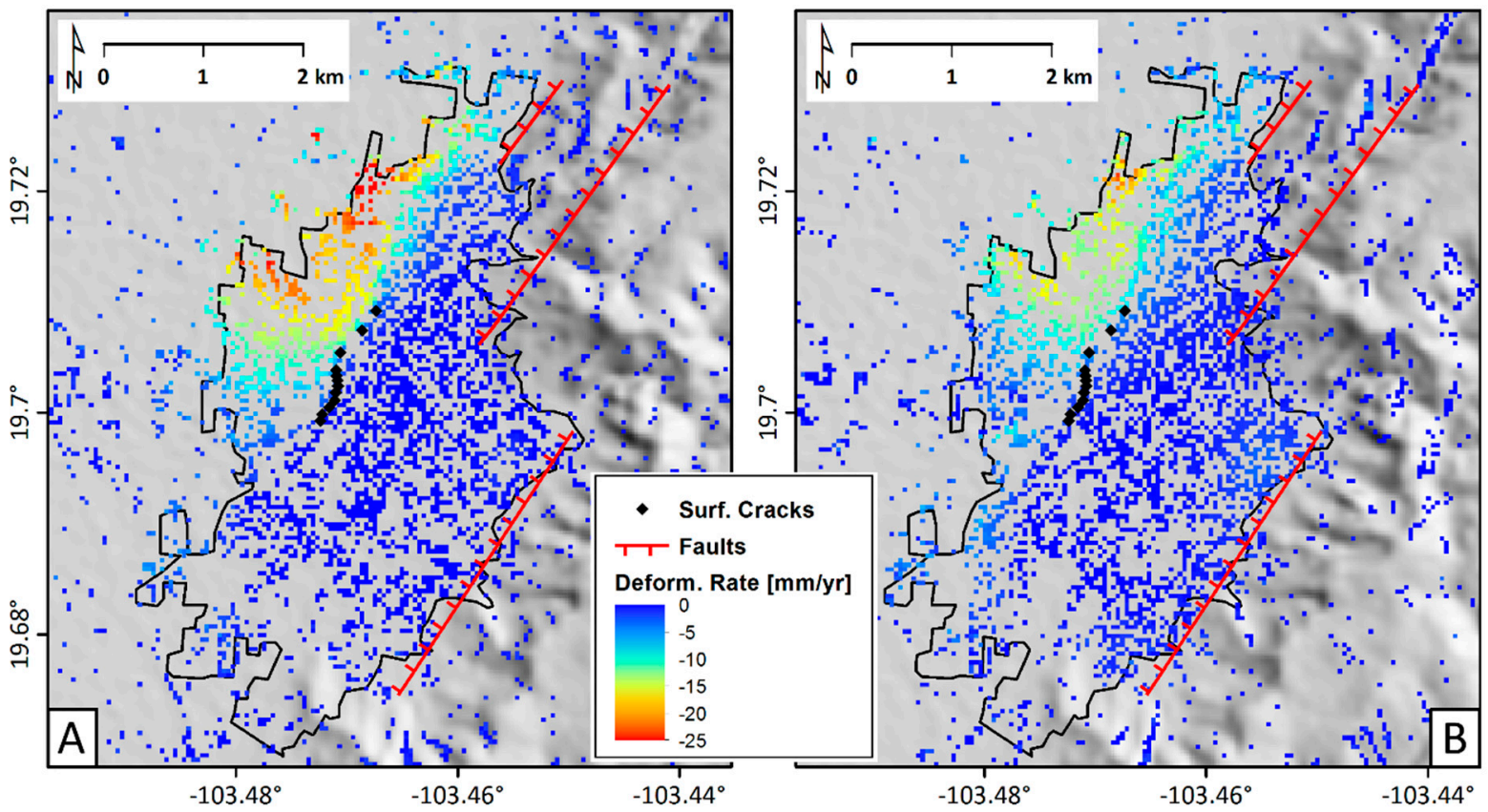

Figure 5. Surface deformation velocities (deformation rate) estimated by the Multi-Baseline method, applied to (a) ascending and (b) descending ENVISAT data. Known faults and the cracks observed on the field are superimposed.
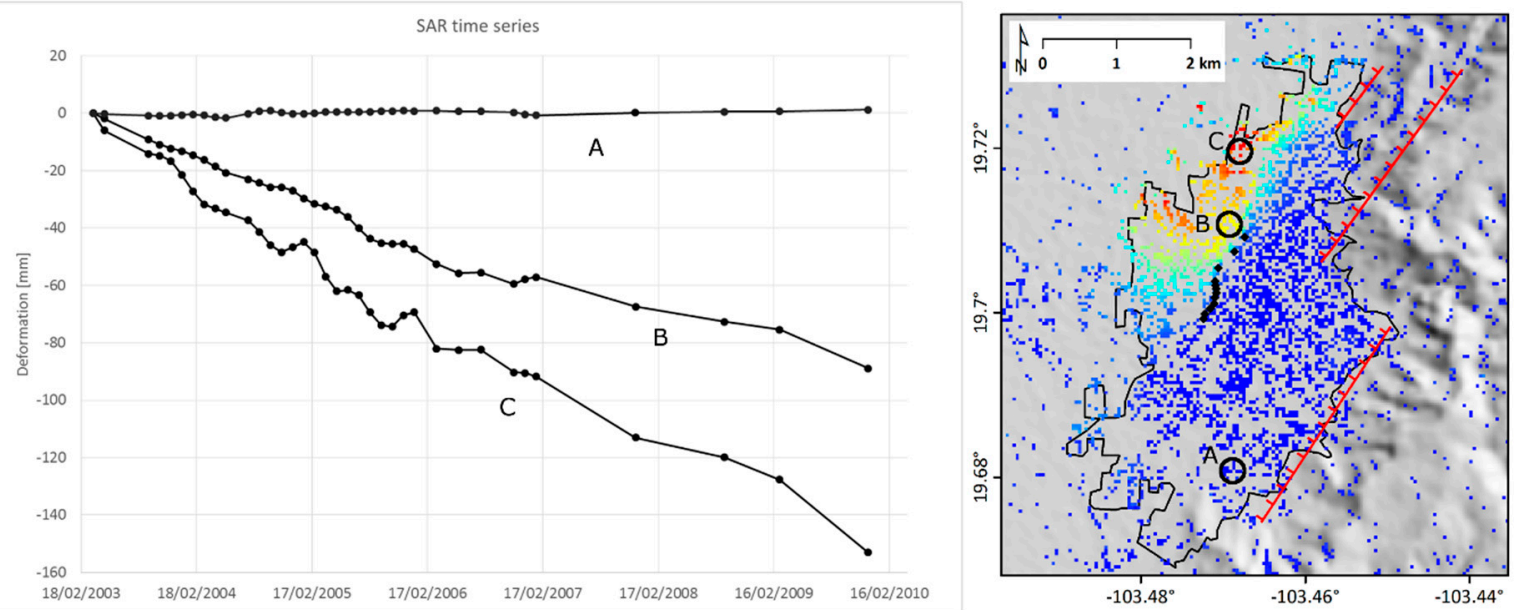

Figure 6. Example of three deformation histories estimated by the Multi-Baseline approach on ENVISAT ascending dataset. Curves A, B, and C are related to the points depicted in the inset (black circles).

The vertical and east-west horizontal components of the deformation have been calculated combining the ascending and descending ENVISAT data (Figure 7). It is well know that space-borne SAR, flying on a quasi-polar orbit, are very weakly sensitive to the north-south component of the deformation (about $8 \%$ for ENVISAT) [42]. Thus, this component is always neglected during displacement estimation. Only a very low percentage of the north-south movement can be detected. These maps confirm that on the Eastern side of CG (i.e., to the east of the observed fissures), the ground is almost stable, with horizontal and vertical deformation rates close to zero. Moving towards west, a sudden increase of the deformation is observed, crossing the fissure alignment. The subsidence rate reaches values of about $25 \mathrm{~mm} / \mathrm{year}$ 
(Figure 7a), together with eastward oriented horizontal movements with a magnitude of about 10-15 $\mathrm{mm} /$ year, i.e., one half of the subsidence rate (Figure $7 \mathrm{~b}$ ).

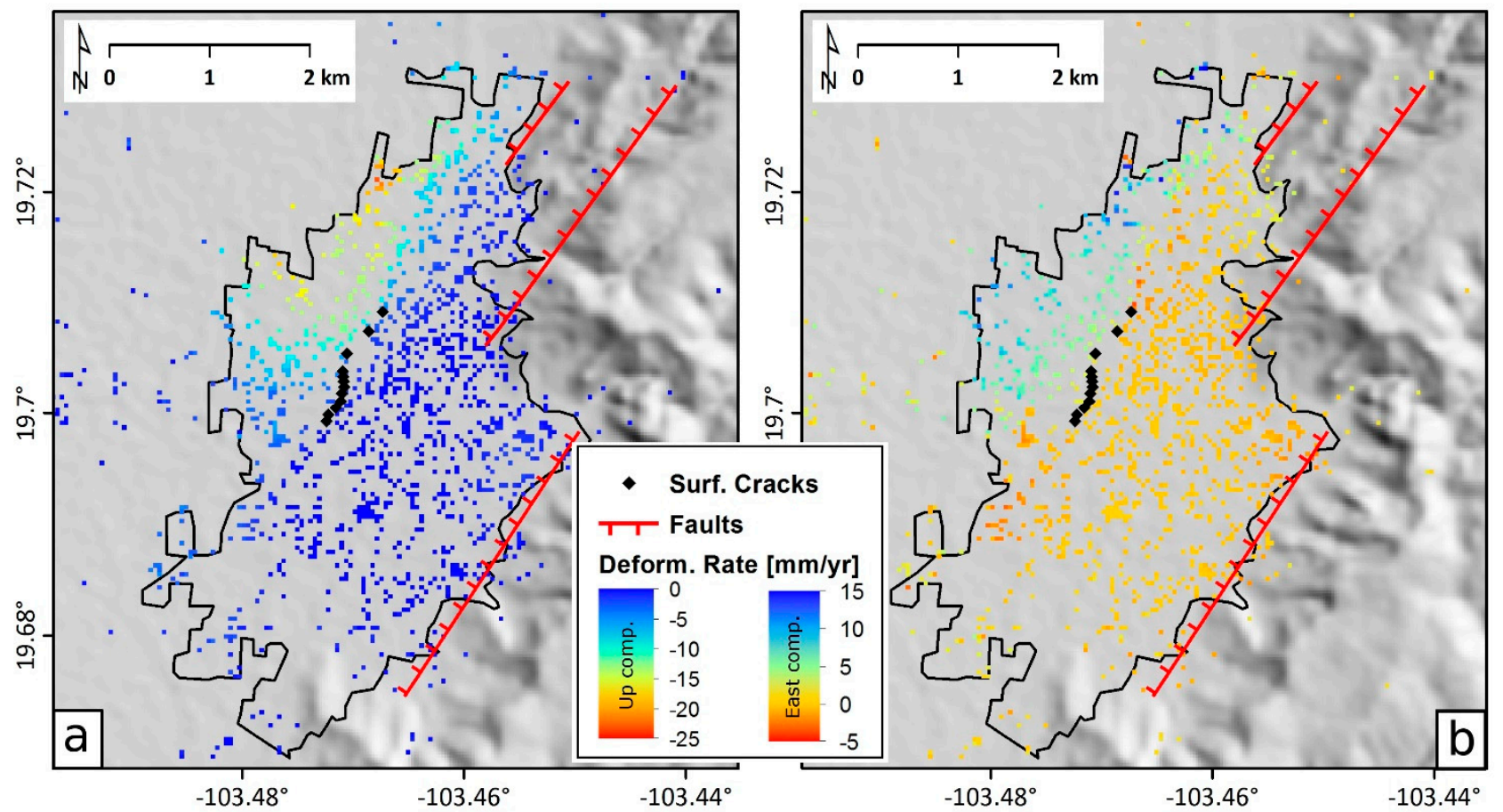

Figure 7. (a) Vertical deformation rate (negative values mean subsidence) and (b) east-west deformation rate (positive values mean eastward movement) computed from ascending and descending ENVISAT data.

Besides the multi-temporal analysis of ENVISAT images, additional SAR data were exploited to further investigate the pre-event deformation prior to the ruptures occurrence. Three descending SAR images from the Canadian RADARSAT-2 mission (6 March, 28 June and 6 September, 2012, Table 2) allowed capturing and measuring the displacement between March and September, 2012, just before the event. We calculated two interferograms by paring 6 March-26 June, and 26 June-6 September images. The resulting deformation maps are reported in Figure 8. Both maps show subsidence located in the same area detected by multi-temporal analysis of ENVISAT data. Also in these two cases, the deformation is confined within the alignment marked by the fissures, with a clear increase in deformation with a spatial extent of $4 \mathrm{~km}^{2}$. Indeed the 26 June- 6 September interferogram shows a larger displaced area with respect to the 6 March-26 June map, and in addition, subsidence increase toward NNW with values reaching $0.5-1.0 \mathrm{~cm}$. Such discrepancy in the observed displacements between the two images is probably caused by the seasonal recharge of the groundwater, which is clearly visible in the slight oscillations of the displacement of point $\mathrm{C}$ in Figure 6.

The rupture event was also analyzed by exploiting RADARSAT-2 images. In this case, we used the additional SAR image acquired on 11 December 2012 (Table 2). This data, combined with the 6 September, image allowed estimation of the co-event deformation (Figure 9). The deformed areas (Figure 9) are very similar to the one already observed in the previous interferometric analyses. In addition, a more pronounced subsidence of $1.5 \mathrm{~cm}$ is visible in the proximity of the surface ruptures. Furthermore, the loss of coherence immediately at NW of the fissures is consistent with the very large 
deformations observed during the field surveys (Table 1). It is worth noting that the image pair used to estimate the co-event deformation has a time lapse of about three months. Therefore, the resulting displacement cannot be considered strictly a co-event one, but additional post-event deformation is present. Indeed, this can be observed looking at the northern section of the subsidence where the values are similar to the pre-event interferogram (Figure $8 b$ ), i.e., more regular in time.

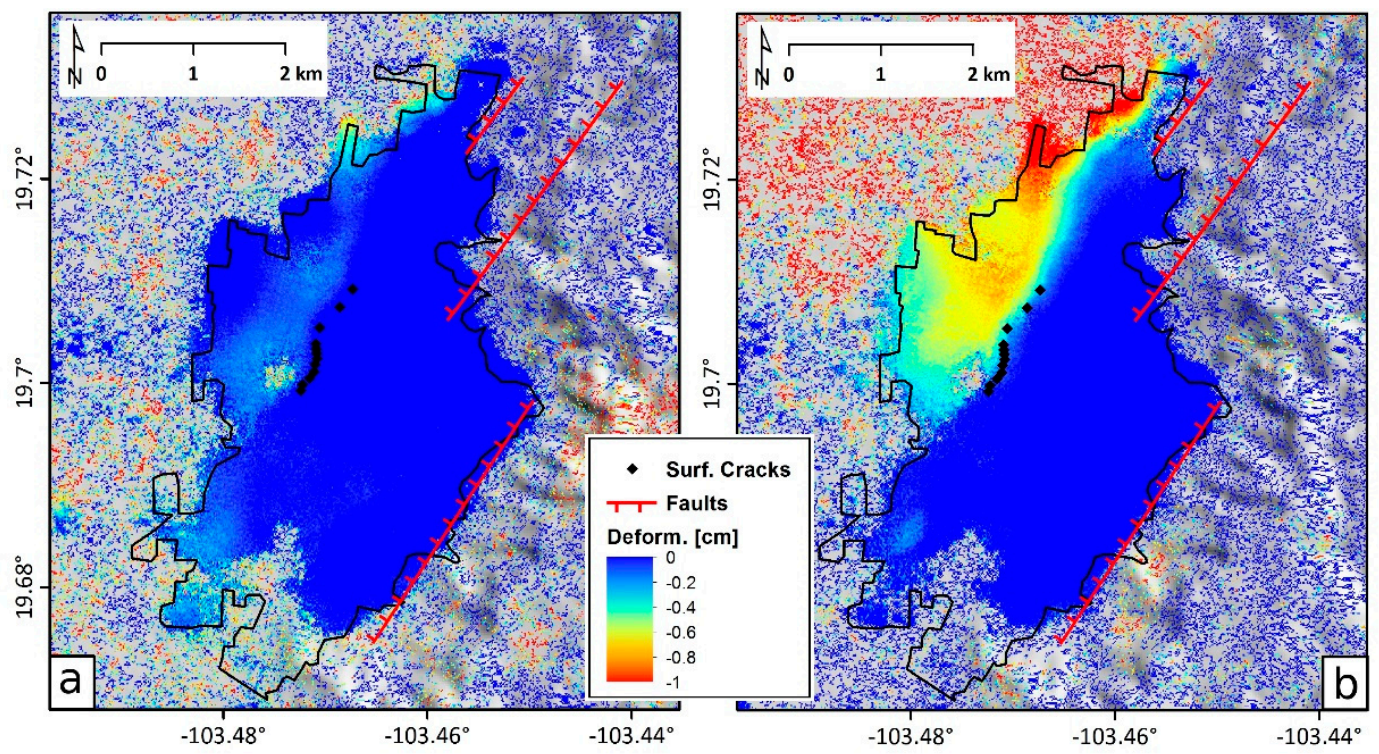

Figure 8. Pre event deformation estimated by exploiting 2012 RADARSAT-2 images: (a) 6 March-26 June differential interferogram, and (b) 26 June-6 September differential interferogram.

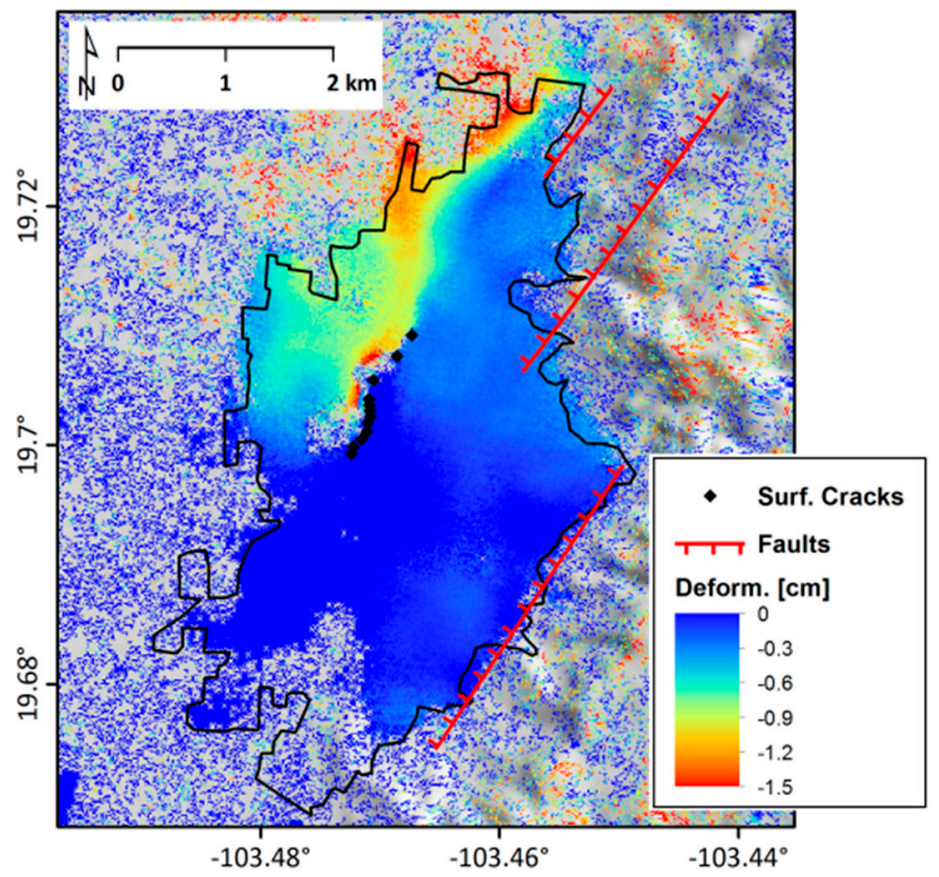

Figure 9. Co-event deformation by means of DInSAR applied to RADARSAT-2 data (6 September-11 December 2012). The maximum measured deformation in LOS is about $1.5 \mathrm{~cm}$, located close to the surface ruptures and in the northern area of CG. The loss of coherence, visible in proximity of the fissures, can be due to a large deformation. 


\section{Discussion}

ENVISAT time series from 2003 to 2010 (Figures 5 and 7) clearly show that the subsidence rate affecting the Eastern side of the town is approximately constant in time, with ground velocities increasing from $0 \mathrm{~mm} /$ year east of the fissures alignment, up to $25 \mathrm{~mm} /$ year northwest of CG. The linearity of the detected deformation likely reflects a consistency in the cause of subsidence. A seasonal oscillation can be noted for points $\mathrm{B}$ and $\mathrm{C}$ in Figure 6, related to the dry and rainy seasons (October to January is the dry season while most of precipitations are concentrated from June to September).

Artificial loading (due to urbanization), natural consolidation, earthquakes, or groundwater withdrawal in general may cause the subsidence phenomenon. Such events may act separately or in combination.

It is unlikely that artificial loading produced by urbanization caused the observed subsidence. Urbanization generally results in subsidence after the load has been applied for at least two decades [43]. A comparison between satellite images of the urban area of CG shows that the urban layout has not changed from 2005 to 2013, suggesting that there is no direct connection with the detected subsidence and fissuring. Furthermore, natural processes such as isostatic sediment loading or consolidation of weak quaternary deposits, which presents typical rates of few millimeters per year [44], cannot explain the detected rapid subsidence rates.

The hydraulic erosion or piping may act as the main process driving the fissuring of September 2012 in CG [37], but a careful analysis of daily rainfall estimation by Tropical Rainfall Measuring Mission (TRMM) over the CG area shows no heavy precipitations or storms prior or during the subsidence event (Figure 10). Because of these reasons, we exclude hydraulic erosion as the main process generating ground deformations.

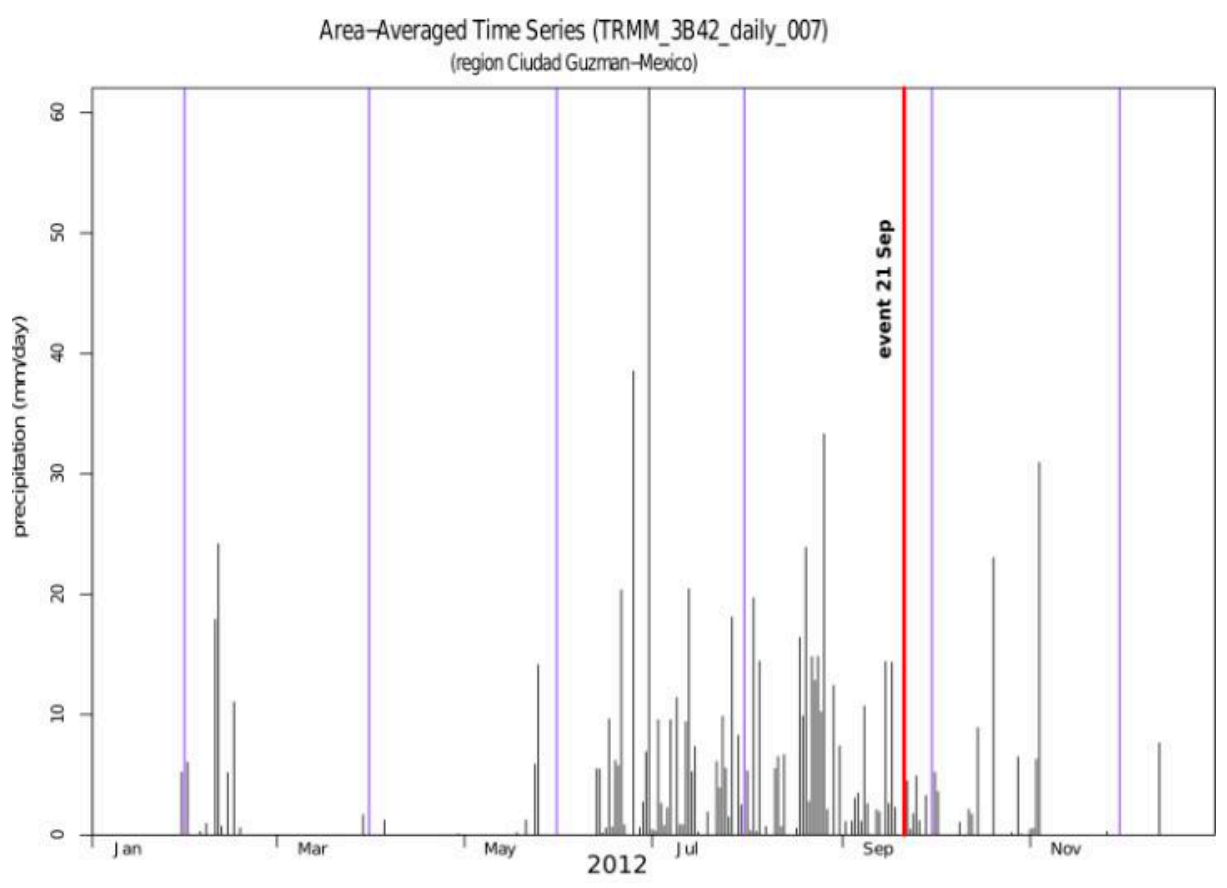

Figure 10. Rainfall estimates from TRMM (Tropical Rainfall Measuring Mission-NASA) 3B42 Daily ver.007 data for 2012. 
The data discussed in Sections 3 and 4 show that ground subsidence extends over a large area and the fissures are aligned NE-SW, suggesting a geometric control of the deep buried structures and the dislocated bedrock. In fact, the NCG bounding faults, prolonged southward under the urbanized area (Figure 2), clearly overlap with the fissures opened on September 2012. These faults probably act as a structural control on the detected subsidence, even if no tectonic deformation occurred, as showed by the lack of any seismic shaking during the 2012 ground deformations. Furthermore, similar observations on the role that existing faults play on subsidence partitioning have already been observed in Mexico [17,23].

Land subsidence caused by compaction of aquifer systems is a worldwide problem in agricultural and urban areas heavily dependent on groundwater supplies. In some places, this kind of land subsidence is associated with structural faults, generating fissures and surface faults due to vertical differential compaction of lacustrine and/or fluvio-lacustrine sediments overlying the faults $[45,46]$. This phenomenon is called Subsidence-Creep-Fault Process (SCFP) $[18,46]$ and is characterized by different stages. The groundwater extraction from the pore spaces in unconsolidated sandy to gravelly aquifers causes a lowering of pore-water pressure. This results in an increase of the effective stress in the highpermeability low-compressibility coarse-grained aquifers and a time-dependent pore-pressure reduction in the low-permeability high-compressibility fine-grained aquitards [47]. The reduction in pore-water pressure produces an increase in the overburden stress, causing the immediate compaction of the soil. If the stress increment due to the groundwater depletion is larger than the preconsolidation stress (i.e., stress ever experienced by these sediments) the deformation is irreversible as it is caused by the non-reversible grain rearrangement of the sediments. Generally, the compaction of thecoarse-grained soils, which constitute the aquifer, is negligible. If the aquifer has silt and clay beds (aquitards) within, the lowered pore-water pressure in the sand and gravel causes the slow drainage of water from the pore spaces in the silt and clay beds, allowing the fine-grained particles to compress or compact. The overall aquifer volume change is due mainly to the compaction of fine-grained sediments. Reaching pore-water pressure equilibrium between aquifers and aquitards may take months or years, and thick clay layers may take hundreds of years to reach equilibrium. Thus, the resulting compaction may continue long after groundwater withdrawals are brought back into equilibrium with groundwater recharge, or cease completely.

In the presence of bedrock dislocated by faults and overlaid by soft sediments, the ground compaction may produce differential settlements depending on the different thickness of sediments, causing tension and fissuring along the surface projection of the buried fault planes. If the process extends over time, one of the borders of the soil fissure sinks (surface fault), generating a scarp at the surface projection of the buried fault planes.

The SCFP is compatible with the subsidence pattern observed in CG by SAR data and with the development of the fissures of September 2012. The observed high gradients of ground velocities occurring on a narrow zone ( $<1 \mathrm{~km}$ wide) suggest that there is a sharp transition between laterally adjacent lithological units juxtaposed by faulting, which present different thickness, compressibility and permeability. In fact, the aquifer of CG is formed by alternating levels of sandy to gravelly layers (acquifers) and silty to clayey levels (aquitards) [32,37]. Furthermore, an important drop of piezometric water level has been reported in CG and in other Mexican cities $[45,48]$. In particular, CG has experienced a reduction in the phreatic level of about $69 \mathrm{~cm}$ per year [37]. 
The connection between SCFP and the development of fissures at ground has been verified with a numerical model of the ground subsidence using the finite element method. A 2D numerical model crossing CG from NW to SE has been developed (Figure 2c). The fully coupled approach proposed by Biot [49] has been considered in the model in order to assess the deformation of porous media that results from fluid withdrawals. The model consists of two materials: the rocky basement, assumed as infinitely stiff and impermeable; and the aquifer body, supposed homogeneous and isotropic. An elastic constitutive model has been assumed for the aquifer body, with the geotechnical parameters listed in Table $3[50]$.

Table 3. Geotechnical parameters for the finite element model of Figure 2c

\begin{tabular}{cccccc}
\hline Material & $\boldsymbol{\rho}\left(\mathbf{k g} / \mathbf{m}^{3}\right)$ & $\mathbf{E}(\mathbf{P a})$ & $\boldsymbol{v}$ & $\mathbf{k}\left(\mathbf{m}^{2}\right)$ & $\mathbf{e}$ \\
\hline Basement & 2400 & - & - & - & - \\
Quaternary soil & 1520 & $6 \mathrm{e} 7$ & 0.26 & $1 \mathrm{e} 8$ & 0.4 \\
\hline
\end{tabular}

$\rho=$ relative density $\mathrm{E}=$ Young modulus; $v=$ Poisson coefficient $\mathrm{k}=$ intrinsic permeability; $\mathrm{e}=$ void index

The model is vertically fixed at the bottom and horizontally sideways. The only force acting is the gravity load. This simplified model is useful for the analysis of the stresses and deformations into the soil mass that caused the surface cracks. Of course, a multi-layered aquifer system is the best solution in order to best fit the observed displacements, but this kind of modeling is not possible at this time because of the lack of data regarding the complex aquifer system, the exact geometry of the buried faults and the amount of the extracted water.

The modeling has been performed in two steps. At first stage, a physically valid distribution of in-situ stress state is obtained by applying the gravity load. The groundwater table is horizontal at the ground level and pore pressures present a hydrostatic stress distribution. In the second stage, the water table is lowered in order to simulate the displacements observed by the ENVISAT data during 2003-2010. Since the information regarding the amount of the extracted water during this period is missing, we assumed a mean groundwater loss of $67 \mathrm{~cm} /$ year, for a total reduction of about five meters in six years. The selected rate corresponds to the annual phreatic surface reduction observed until 2004 [37]. This assumption is valid because generally the water demand tends to increase increases following the population growth. Certainly, there is the possibility that between 26 June-2012 and 6 September 2012 a strong variation of the water table has happened, causing the deformation pattern in Figure $8 \mathrm{~b}$. Anyway this aspect enforces the hypothesis of a connection between groundwater changes and the ground fissures. A first comparison between observed and calculated LOS ENVISAT displacement profiles at 2010 (Figure 11a,b) shows a fairly good agreement, despite the simplicity of the adopted model. The displacements are overestimated to the eastern part.

Such discrepancy is probably due to the presence of different lithology, which has different subsidence potentials [50,51], or because the groundwater depletion is uneven, thus it does not affect the east side of CG. Moreover, the presence of buried faults, which act as a barrier to groundwater flow, may produce differential subsidence [45], but such feature is not introduced in our model because of the lack of field data. 


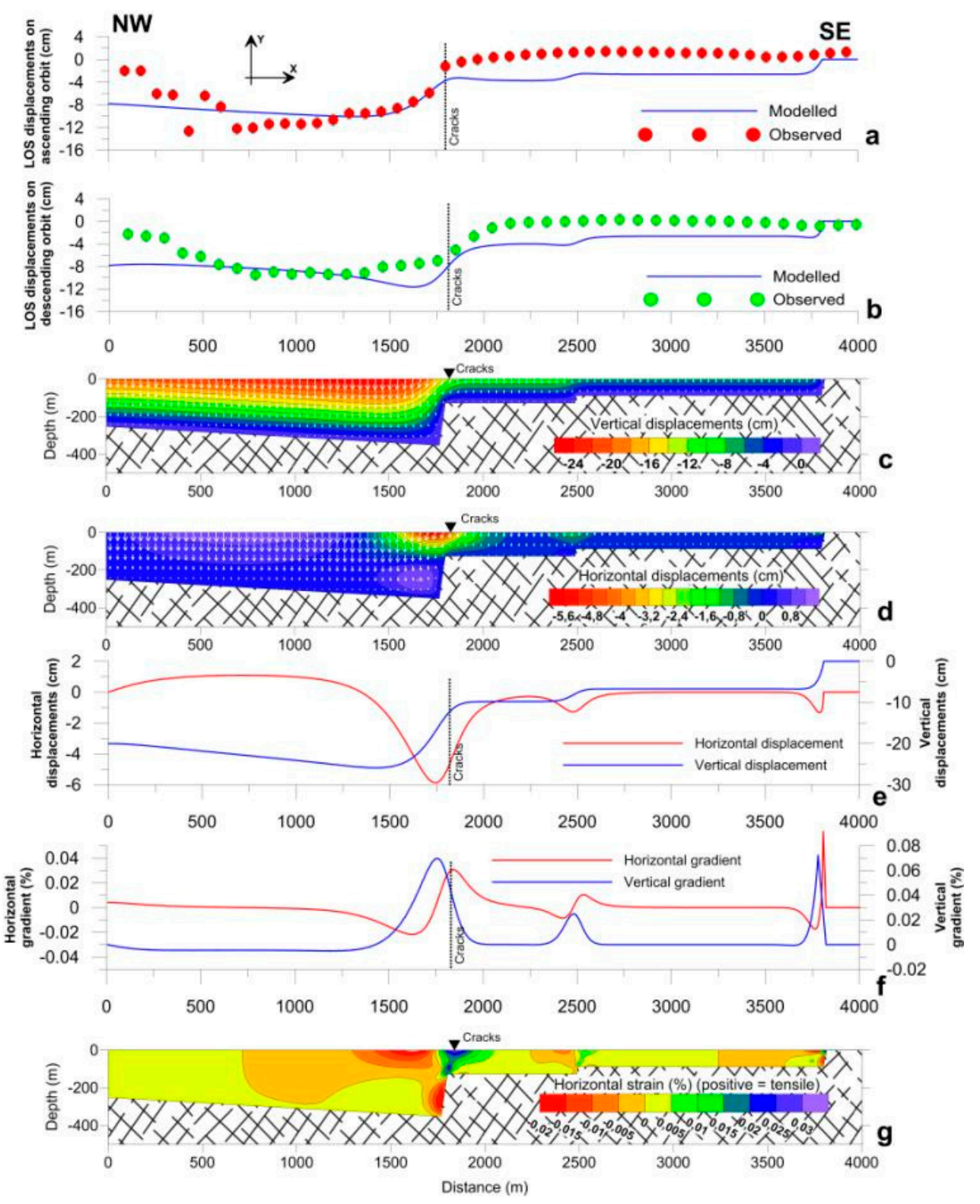

Figure 11. Comparison between calculated and observed LOS displacements considering the cumulated displacements of (a) ascending and (b) descending ENVISAT data. (c) Vertical and (d) horizontal displacement contours, together with the resultant displacement vectors. (e) Horizontal and vertical displacement profiles at the ground level. (f) Horizontal and vertical gradient at the ground level. (g) Contour of the horizontal strains after the lowering of the water table.

In order to explain the features of the observed displacement and the development of ground fissures, the results of the numerical model are shown in terms of horizontal and vertical displacement profiles and contours, and horizontal strains.

Generally, a uniform lowering of the water table, as we modeled in this case, produces only vertical displacements when the thickness of the compacting stratum is constant. In presence of sudden discontinuities and/or gradual changes in sediment thickness, the magnitude of vertical displacements depends strictly on the thickness of the compacting soil, giving rise to the development of a complex pattern. For the CG model, the vertical displacements increase towards NW, following the higher 
thickness of the compacting stratum (Figure 11c) as it can be clearly seen by observing the vertical ground displacement profile in Figure 11e.

Moreover, a change in the thickness produces some local horizontal movements. The soil mass in the ticker part, subjected to higher vertical deformation, pulls the soil in the thinner part towards the deeper side of the profile; this effect causes the horizontal movement of the soil particles. In fact, the modeled thickness heterogeneity causes horizontal displacements close to the surface. More in detail, SE directed horizontal movements develop between 0 and 1250 meters (Figure 11d,e). These displacements are in agreement with the observed horizontal displacements in Figure $7 \mathrm{~b}$ and are mainly driven by the gradual increment of the sediment thickness towards SE. The difference in magnitude between the observed and computed horizontal displacements (Figures 11e and 7b) depends strictly on the geometry of the bedrock, which probably is more complex than the one we modeled, and also on the uneven groundwater depletion. Such horizontal displacements are distributed over a large area thus they do not develop high horizontal strains (Figure 11e). Moreover, larger values of NW directed horizontal displacements develop close to the surface projection of the buried fault at about 1200 meters (Figure 11d,e).

The general displacement is well represented in Figure $11 \mathrm{c}, \mathrm{d}$. At the left of the model (i.e., at $0 \mathrm{~m}$ ), the vectors are oriented downward because of the imposed constraint on the horizontal displacements. This is an artifact of the model, which produces zero horizontal displacements. Proceeding to the right, the vectors are slightly rotated towards SE, until they rotate towards NW close to the buried fault. This displacement pattern justifies the development of ground fissures. In fact, the modeled horizontal and vertical displacement profiles (Figure 11e) show high gradients in proximity of the cracks (Figure 11f), where the thickness of the compressible stratum changes because of the buried fault. In particular, maximum vertical displacements in this area are about four times higher than horizontal displacements, suggesting a dominant role of the vertical displacements in the development of fractures. This result is consistent with the geometry of the observed fissures, which show a main vertical offset.

Because the horizontal particle movement is not uneven along the surface, it causes horizontal strain, and the possible generation of ground fissures. In fact, in the area between 0 and 1000 meters, the horizontal strains are generally positive, indicating compression. Contrariwise, maximum tensile horizontal strains are localized in a narrow zone at the surface (at about 1200 meters in Figure 10f), coinciding with the position of the observed ground cracks. This suggests that ground fissures are mainly driven by vertical displacements, but develop in narrow zones characterized by high values of tensile strains. Such phenomenon could be enhanced by the presence of faults with different mechanical and hydraulic properties with respect to the neighboring soils, and by the presence of a superficial brittle unsaturated zone [52,53].

\section{Conclusions}

Slow surface subsidence field, fast ground fissuring and their relationships with morphology and tectonic structures of the CG area have been studied by means of advanced InSAR techniques, structural field survey and numerical modeling. ENVISAT time series (2003-2010) clearly show that ground subsidence rate affecting the northwestern side of the town is approximately constant in time, with ground velocities increasing $0 \mathrm{~mm} /$ year up to $25 \mathrm{~mm} /$ year. Pre- and co-fracturation ground displacements processes in CG show similar patterns to structural observations in the field. The subsidence phenomenon 
in CG is the primary consequence of artificial subsoil water pumping, probably in combination with other factors linked to subsurface water circulation (such as local piping) or tectonic activity. We conclude that the progressive accumulation of strains due to ground subsidence caused by groundwater depletion has produced the observed fissures of September 2012. In particular, the progressive sediment compaction produced by the groundwater overexploitation results in a complex displacement pattern, strictly dependent on irregularities in the hydrologic basement and on the presence of discontinuities such as buried faults. In fact, differential vertical displacements produce horizontal displacements at ground level, which are localized close to the projection at ground level of the buried faults, thus leading to the development of tensile horizontal strains. The fracturing is mainly driven by vertical displacements, but it manifests where high gradients of horizontal strains develop. However, the assumption of a homogeneous aquifer body may lead to a wrong estimation of strain distributions.

Further work is required to characterize the complex geometry and the elastic and hydraulic characteristics of the aquifer system in order to predict the future development of fractures. In fact, this phenomenon may still occur in the future with an even greater impact on CG buildings, roads and urban facilities. It is evident that the entire basin is affected by ground subsidence and requires careful land use planning throughout the basin to create a sustainable environment by means of the regulation of groundwater extraction, improvement in agricultural practices, and better water and wastewater management policies.

\section{Acknowledgments}

We thank Matteo Roverato and Julia Kubanek for the support during fieldwork. The Ministry of Foreign Affairs of Italy and SRE of Mexico provided travel assistance to Gianluca Groppelli. The grant CONACyT CB-2009-132265 provided travel assistance to Gianluca Norini. We thank the Canadian Space Agency for providing RADARSAT-2 data; ESA provided ENVISAT-ASAR data within the C1.P project 6435 . We thank G.C. Ruta for his careful and critical reading of the manuscript. We are indebted to the anonymous reviewers for the detailed and insightful comments that substantially improved the clarity of the paper. Finally, we are greatly indebted to Carlos Suàrez-Plascencia (University of Guadalajara, Mexico) for the valuable information about the event in September 2012.

\section{Author Contributions}

All authors participated in manuscript writing and have read and approved the final manuscript. Carlo Alberto Brunori, Francesco Zucca and Salvatore Stramondo developed the project, analyzed and interpreted the data. Christian Bignami and Sergey Samsonov have processed the SAR data. Matteo Albano and Michele Saroli developed the numerical modeling and help in the geological interpretation. Gianluca Groppelli conducted the survey in the field and contributed to the production of the geological model. Gianluca Norini gave a significant contribution to relate the geological model with the Northern Colima Graben tectonic. 


\section{Conflicts of Interest}

The authors declare no conflict of interest.

\section{References}

1. Bouwer, H. Land subsidence and cracking due to ground-water depletion. Ground Water 1977, 15, 358-364.

2. Ferretti, A.; Novali, F.; Bürgmann, R.; Hilley, G.; Prati, C. InSAR permanent scatterer analysis reveals ups and downs in San Francisco Bay Area. Eos Trans. AGU 2004, 85, 317-324.

3. Mazzotti, S.; Lambert, A.; Van der Kooij, M.; Mainville. A. Impact of anthropogenic subsidence on relative sea-level rise in the Fraser River delta. Geology 2009, 37, 771-774.

4. Rosen, P.A.; Hensley, S.; Joughin, I.R.; Li, F.K.; Madsen, S.N.; Rodriguez, E.; Goldstein, R.M. Synthetic aperture radar interferometry. Proc. IEEE 2000, 88, 333-382.

5. Sansosti, E.; Casu, F.; Manzo, M.; Lanari, R. Spaceborne radar interferometry techniques for the generation of deformation time series: An advanced tool for Earth's surface displacement analysis. Geophys. Res. Lett. 2010, 37, doi:10.1029/2010GL044379.

6. Cigna, F.; Del Ventisette, C.; Liguori, V.; Casagli, N. Advanced radar-interpretation of InSAR time series for mapping and characterization of geological processes. Nat. Hazards Earth Syst. Sci. 2011, $11,865-881$.

7. Hooper, A.; Bekaert, D.; Spaans, K.; Arikan, M. Recent advances in SAR interferometry time series analysis for measuring crustal deformation. Tectonophysics 2012, 514-517, 1-13.

8. Lubitz, C.; Motagh, M.; Wetzel, H.U.; Kaufmann, H. Remarkable urban uplift in Staufen im Breisgau, Germany: Observations from TerraSAR-X InSAR and leveling from 2008 to 2011. Remote Sens. 2013, 5, 3082-3100.

9. Gourmelen, N.; Amelung, F.; Casu, F.; Manzo, M.; Lanari, R. Mining-related ground deformation in Crescent Valley, Nevada: Implications for sparse GPS networks. Geophys. Res. Lett. 2007, 34, doi:10.1029/2007GL029427.

10. Samsonov, S.V.; González, P.J.; Tiampo, K.F.; D’Oreye, N. Modeling of fast ground subsidence observed in southern Saskatchewan (Canada) during 2008-2011. Nat. Hazards Earth Syst. Sci. 2014, 14, 247-257.

11. Geertsma J. Land subsidence above compacting oil and gas reservoirs. J. Pet. Technol. 1973; 25, 734-744.

12. Bawden, G.W.; Thatcher, W.; Stein, R.S.; Hudnut, K.W.; Peltzer, G. Tectonic contraction across Los Angeles after removal of groundwater pumping effects. Nature 2001, 412, 812-815.

13. Stramondo, S.; Saroli, M.; Tolomei, C. ; Moro, M.; Doumaz, F.; Pesci, A.; Boschi, E. Surface movements in Bologna (Po Plain-Italy) detected by multitemporal DInSAR. Remote Sens. Environ. 2007, 110, 304-316.

14. Samsonov, S.; Tiampo, K.; Gonzlez, P.J.; Manville, V.; Jolly, G. Ground deformation occurring in the city of Auckland, New Zealand, and observed by Envisat interferometric synthetic aperture radar during 2003-2007. J. Geophys. Res.: Solid Earth 2010, doi:10.1029/2009JB006806. 
15. Samsonov, S.; D’Oreye, N.; González, P.J.; Tiampo, K.F.; Ertolahti, L.; Clague, J.J. Rapidly accelerating subsidence in the Greater Vancouver region from two decades of ERS-ENVISAT-RADARSAT-2 DInSAR measurements. Remote Sens. Environ. 2014, 143, 180-191.

16. González, P.J.; Fernández, J. Drought-driven transient aquifer compaction imaged using multitemporal satellite radar interferometry. Geology 2011, 39, 551-554.

17. Chaussard, E.; Wdowinski, S.; Cabral-Cano, E.; Amelung F. Land subsidence in central Mexico detected by ALOS InSAR time-series. Remote Sens. Environ. 2014, 140, 94-106.

18. Garduño, M. V.; Arregue, R. E.; Israde, A. I.; Rodríguez, G. T. Efectos de las fallas asociadas a sobreexplotación de acuíferos y la presencia de fallas potencialmente sísmicas en Morelia, Michoacán, México. Revista. Mexicana de Ciencias. Geológica. 2001, 18, 37-54.

19. Carreón-Freyre, D.; Cerca, M.; Hernandez-Marin, M. Correlation of near-surface stratigraphy and physical properties of clayey sediments from Chalco Basin, Mexico, using Ground Penetrating Radar. J. Appl. Geophys. 2003, 53, 121-136.

20. Brunori, C.A.; Bignami, C.; Zucca, F.; Groppelli, G.; Norini, G.; Hernández, N.D.; Stramondo, S. Ground Fracturation in Urban Area: Monitoring of land subsidence controlled by buried faults with InSAR Techniques (Ciudad Guzmán: Mexico). In Engineering Geology for Society and Territory; Springer: Berlin/Heidelberg, Germany, 2015; pp. 1027-1031.

21. Suárez Plascencia, C. Internal Report by Unidad Estatal de Protección Civil y Bomberos de Jalisco; Universidad de Guadalajara: Jalisco, México, 2012.

22. Ferrari, L.; Orozco-Esquivel, T.; Manea, V.; Manea, M. The dynamic history of the Trans-Mexican Volcanic Belt and the Mexico subduction zone. Tectonophysics 2012, 522, 122-149.

23. Carreón-Freyre, D. Land subsidence processes and associated ground fracturing in central Mexico. In Proceedings of 8th International Syposium on Land Subsidence, Querétaro, Mexico, 17-22 October 2010.

24. Carreón-Freyre, C.J.; Cerca, M.; Gámez González, F.J.; González, L.L. Influencia de la estratigrafía y estructura geológica en el flujo de agua subterránea del Valle de Querétaro. Rev. Mex. Ciencias. Geológicas. 2005, 22, 1-18.

25. Luhr, J.F.; Nelson, S.A.; Allan, J.F.; Carmichael, I.S.E. Active rifting in Southwestern Mexico: Manifestations of an incipient eastward spreading-ridge jump. Geology 1985, 13, 54-57.

26. Allan, J.F. Geology of the Northern Colima and Zacoalco Grabens, Southwest Mexico: Late Cenozoic rifting in the Mexican volcanic belt. Geol. Soc. Am. Bull. 1986, 97, 473-485.

27. Allan, J.F.; Nelson, S.A.; Luhr, J.F.; Carmichael, I.S.E.; Wopat, M.; Wallace, P.J. Pliocene-Holocene rifting and associated volcanism in southwest Mexico: An exotic terrane in the making. In The Gulf and Peninsular Province of the Californias; American Association of Petroleum Geologists: Oklahoma, OK, USA, 1991; pp. 425-445.

28. Suárez, G.; García-Acosta, V.; Gaulon, R. Active crustal deformation in the Jalisco block, Mexico: evidence for a great historical earthquake in the 16th century. Tectonophysics 1994, 234, 117-127.

29. Garduño, V.H.; Tibaldi, A. Kinematic evolution of the continental active triple junction of the western Mexican volcanic belt. Comptes Rendus l'Académie Sci. 1991, 312, 135-142.

30. Ferrari, L., Garduno, V.H.; Pasquarè, G.; Tibaldi A. Volcanic and tectonic evolution of central Mexico: Oligocene to present. Geofis. Int. 1994. 33, 91-105. 
31. Norini, G.; Capra, L.; Groppelli, G.; Agliardi, F.; Pola. A.; Cortes, A. Structural architecture of the Colima Volcanic Complex. J. Geophys. Res.: Solid Earth 2010, 115.

32. Gutierrez-Martinez, C.A.; Franco-Sànchez, M. Análisis de "efecto de sitio" en Ciudad Guzmán, Jalisco, México. Available online: http://www.funvisis.gob.ve/archivos/www/terremoto/Papers/ Doc001/doc001.htm (accessed on 18 March 2015).

33. MSC Software Corporation. MSC Marc 2013. User guide. Available online: https://simcompanion (accessed on 2 February 2015).

34. Rosas-Elguera, J.; Ferrari, L.; Garduño-Monroy, V.H.; Urrutia-Fucugauchi, J. Continental boundaries of the Jalisco block and their influence in the Pliocene-Quaternary kinematics of western Mexico. Geology 1996, 24, 921-924.

35. Singh, S. K.; Ordaz, M.; Pérez-Rocha, L. E. The great Mexican earthquake of 19 June 1858: Expected ground motions and damage in Mexico City from a similar future event. Bull. Seismol. Soc. Am. 1996, 86, 1655-1666.

36. Servicio Sismológico Nacional de Mexico. Available online: http://www2.ssn.unam.mx:8080/ website/jsp/catalogo2.jsp (accessed on 4 February 2015).

37. Padilla Corona, E. Geotecnical, analysis of the formation of earth fissures at Ciudád Guzman, Jalisco, In Proceedings of 5th International Conference on Case Histories in Geotechnical Engineering, New York, NY, USA, 13-17 April 2004.

38. Ortiz-Jimenez, M.A.; De Anda, J.; Shear, H. Hydrologic balance of lake Zapotlàn, Mexico. $J$. Environ. Hydrol. 2005, 13, 1-16.

39. Werner, C.; Wegmüller, U.; Strozzi, T.; Wiesmann, A. Interferometric Point Target Analysis for deformation mapping. In Proceedings of the 2003 IEEE Geoscience and Remote Sensing Symposium (IGARSS), Melbourne, Australia, 21-25 July 2003.

40. Berardino, P.; Fornaro, G.; Lanari, R.; Sansosti, E. A new algorithm for surface deformation monitoring based on small baseline differential SAR interferograms. IEEE Trans. Geosci. Remote Sens. 2002, 40, 2375-2383.

41. Schmidt, D.A. Time-dependent land uplift and subsidence in the Santa Clara valley, California, from a large interferometric synthetic aperture radar data set. J. Geophys. Res.: Solid Earth 2003, doi:10.1029/2002JB002267.

42. Fialko, Y.; Simons, M.; Agnew, D. The complete (3-D) surface displacement field in the epicentral area of the 1999 Mw7. 1 Hector Mine earthquake, California, from space geodetic observations. Geophys. Res. Lett. 2001, 28, 3063-3066.

43. Polcari, M.; Albano, M.; Saroli, M.; Tolomei, C.; Lancia, M.; Moro, M.; Stramondo, S. Subsidence detected by multi-pass differential SAR interferometry in the Cassino Plain (central Italy): Joint effect of geological and anthropogenic factors? Remote Sens. 2014, 6, 9676-9690.

44. Holzer, T.L. Ground failure induced by ground-water withdrawal from unconsolidated sediment. Rev. Eng. Geol. 1984, 6, 67-106.

45. Chaussard, E.; Bürgmann, R.; Shirzaei, M.; Fielding, E.J.; Baker, B. Predictability of hydraulic head changes and characterization of aquifer system and fault properties from InSAR-derived ground deformation. J. Geophys. Res.: Solid Earth 2014, 119, 6572-6590.

46. Avila-Olivera, J.A.; Garduño-Monroy, V.H. A GPR study of subsidence-creep-fault processes in Morelia, Michoacán, Mexico. Eng. Geol. 2008, 100, 69-81. 
47. Terzaghi, K.V. Relation between soil mechanics and foundation engineering. In Proceedings of the 1936 International Conference on Soil Mechanics and Foundation Engineering, Boston, MA, USA, 22-26 June 1936.

48. Estadísticas del Agua en México, Edición 2013-Conagua-Comisión Nacional del Agua, Annual report. Available online: www.conagua.gob.mx/CONAGUA07/Noticias/SGP-2-14Web.pdf_accessed on 18 March 2015).

49. Biot, M.A. General theory of three-dimensional consolidation. J. Appl. Phys. 1941, 12, 155-164.

50. Pacheco, J.; Arzate, J.; Rojas, E.; Arroyo, M.; Yutsis, V.; Ochoa, G. Delimitation of ground failure zones due to land subsidence using gravity and finite element modeling in the Queretato valley, Mexico. Eng. Geo. 2006, 84, 143-160.

51. Caine, J.S.; Evans, J.P.; Forster, C.B. Fault zone architecture and permeability structure. Geology 1996, 24, 1025-1028.

52. Burbey, T.J. The influence of faults in basin-fill deposits on land subsidence, Las Vegas Valley, Nevada, USA. Hydrogeol. J. 2002, 10, 525-538.

53. Hernandez-Marin, M.; Burbey, T.J. Fault-controlled deformation and stress from pumping-induced groundwater flow. J. Hydrol. 2012, 428, 80-93.

(C) 2015 by the authors; licensee MDPI, Basel, Switzerland. This article is an open access article distributed under the terms and conditions of the Creative Commons Attribution license (http://creativecommons.org/licenses/by/4.0/). 